\title{
A Collection of Qur'anic Codices
}

\section{by Adam Gacek}

The eighteen copies of the Qur'an described below come from a larger collection of Islamic manuscripts preserved in the Department of Rare Books and Special Collections and introduced in my two previous articles published in this journal.' These Qur'anic codices clearly stand out as a small but nevertheless interesting collection covering various periods and geographical regions. From the codicological point of view, this collection consists of twenty-nine individual codices, or portions thereof, as the nos. 16 and 18 are made up of eleven and two surviving parts, respectively.

Les dix-buit exemplaires du Coran décrits ci-dessous proviennent d'une plus vaste collection de manuscrits islamiques du département des livres rares et des collections spéciales auxquel j'ai déjà consacré deux articles.' Ces manuscrits coraniques constituent une petite collection, qui n'en demeure pas moins intéressante, sur les diverses périodes et régions géographiques. Du point de vue codicologique, cette collection comprend vingt-neuf manuscrits individuels (codices) ou parties de manuscrits puisque les numéros 16 et 18 comprennent respectivement onze et deux parties subsistantes.

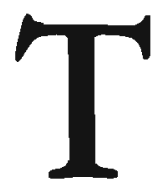
he Qur'an is traditionally regarded as the first Arabic codex par excellence, even though in the early years of Islam the text of the Qur'an was copied in other forms, including loose sheets and scrolls. ${ }^{2}$ The terms subuf (sg. sabîfab) and mushaf (or mashaf, pl. masâhif), which we encounter in the early Arabic sources were used very loosely and did not necessarily convey a particular form of the book. ${ }^{3}$ However, according to Arabic tradition, the Qur'anic text was also copied, from an early period, in booklets (daftar, pl.dafâtir, kurrâs or kurrâsab, pl. karârîs), that is sections of bi-folios consisting of perhaps eight to fourteen single leaves (folios). These booklets came to be placed between two wooden boards (bayna al-daffatayn) and held together by means of clasps, consisting of knobs (zirr, pl. azrâr) and fasteners ('urwah, pl. 'uran). ${ }^{4}$ The bound codex was originally referred to as sifr or mushaf, the latter indicating something which holds subuf together. ${ }^{5}$ Because the companions of the Prophet disliked the word sifr on account of its usage among the Jews, the word mushaf, with the usual epithet al-sharîf, came to be widely accepted as referring to a copy of the Qur'an in the codex form. ${ }^{6}$
The word mushaf is, nevertheless, not the only word which the Muslims have used for the Qur'an. The other two words which we often encounter are khatmab (pl. khatamât, kbitam) and rab'ab (pl. raba'at). The former implies a complete text in one volume and the latter takes its name from a square-shaped box of the same name, which housed a Qur'an divided into a number of codices. This number was usually seven or thirty following the traditional division of the text which allows the Muslim to recite it either in seven or thirty days. ${ }^{7}$ The square-like shape of the box, also referred to in the Maghreb as tâbut (pl. tawabit), it seems, influenced the format of the $r a b^{\prime} a b$. This term was predominantly used in the Maghreb (from Egypt to Andalusia). An excellent example of this kind of $r a b^{\prime} a b$ is our codex no.7. In the Mashriq the term predominantly used for such a box was sundîq (pl. sanâd $\hat{q}$ ) It is interesting therefore to note in this connection the name of the person mentioned in the waqf-statement (no.16) who is referred to as al-Sundûqî, i.e. the keeper of the box.

The text of the Qur'an was originally devoid not only of diacritical marks and vocalization, 


\section{A Collection of Quranic Codices}

but also lacked any headings, verse dividers or other editorial devices. The Arabic tradition tells us that the first thing which was introduced to the text were three dots written at the head of the verse. ${ }^{8}$ Despite the controversies which existed among the early theologians and traditionists regarding the purity of the original text, with time the Qur'an was not only vocalized and provided with chapter headings, but also became an object of the greatest attention on the part of the binder, calligrapher and illuminator. Its production was an act of worship governed by a set of rules called $a d a b$ (etiquette).

As mentioned earlier, the Qur'an was usually divided into seven or thirty parts called manzil (pl. manâzil) and juz' (pl. ajzâ'), respectively. Each juz' could then be sub-divided into two halves referred to as nisf or hizb and four quarters $\left(r u b^{6}\right)$. Other subdivisions included thulth or thalathat arbâ' (as in nos.8, 10,11) and thumn (no. 13). During the recitation of the Qur'an, the Muslim is instructed to perform a number of prostrations (sajdab) and bowings $\left(r u k \hat{u}^{\prime}\right.$, abbr, 'ayn). There are either fourteen or fifteen prostrations all together, usually marked as such in the margin. What is more, the 114 chapters (sîrab) are divided into verses $(a y a b)$ which are often grouped into five (khams, pl. akbmâs) or ten ('ashr, pl. a'shâr) and indicated by means of medallions called khâmisab (pl. khawâmis) and 'âshirab (pl. 'awâsbir).

The eighteen copies of the Qur'an described below represent a variety of styles and decorative techniques used in different periods and regions. The largest group is formed of manuscripts which can broadly be characterized as being of Indo-Pakistani provenance. Here we find a superbly executed copy from Hayderâbâd (no.5), bound in very elegant lacquered covers and exhibiting a Kashmîrî style of decoration. The other copies worth mentioning here are: a large Bihârî Qur'an (no. 14), which is very likely to have been used originally in a mosque and another Bihârî copy (no. 16) produced in or before 908/1503 and containing a valuable waqf-note. There are also five copies of Turkish provenance (nos. 1,2,3,4 and 9), including a seventeenthcentury codex produced by the lmam of
Mehmet the Conqueror's Mosque, as well as one copy from each of the following countries or geographic regions: Egypt (7), Maghreb (6) and Sudan (13).

From the point of view of paleography and codicology this small collection provides us with a number of valuable data. It is worth mentioning here, for example, the Mamluk codex (no. 7), written on a characteristic paper of local manufacture, copied in a script which many refer to as Mamluk Naskh and bound in superbly tooled leather covers of the period. Although not dated, this codex is an excellent example of Arabic book-making in the Mamluk period. Of interest here too is the African codex (no. 13) and in particular its binding which features a single piece of leather with a leather thong attached to the end of the envelope flap. This type of binding was meant to be used as a type of portfolio holding loose leaves or quires. This appears to be one of the very early ways of "binding" Arabic codices, which survived only in Africa. "Finally, mention should be made of a group of so called Bihârî codices (nos. 8, 14,15, 16 and 18). According to present research, sometime in the 14th century, a script peculiar to India established itself as the main Qur'anic hand of the region and came to be used extensively in the 15 th and 16 th centuries. ${ }^{10}$ However, it is worth bearing in mind that this script was not used exclusively for the copying of the Qur'an. There is a number of extant specimens of this script used as an ordinary book hand. ${ }^{1}$ I have chosen the appellation Bihârî, as the most likely, but it has to be said that this script is referred to in a variety of publications as kbatt-i bihâr, khatt-i bihâr, khatt-i bâhar,

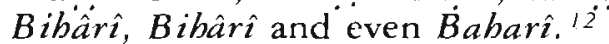

In my description of the Qur'anic codices I have tried to indicate the existence or nonexistence of tarwîs in a given hand. Although it is too early to draw any firm conclusions, there is no doubt that this line of inquiry will one day bear some fruit. At this stage, for example, it can be said that the use of rightsloping or left-sloping tarwis in the Naskh script is indicative of the influence of either Arabo-Turkish or Persian schools of calligraphy, respectively. The tarwis in this script, when executed by the calligraphers of the 
A Collection of Quramic Condices

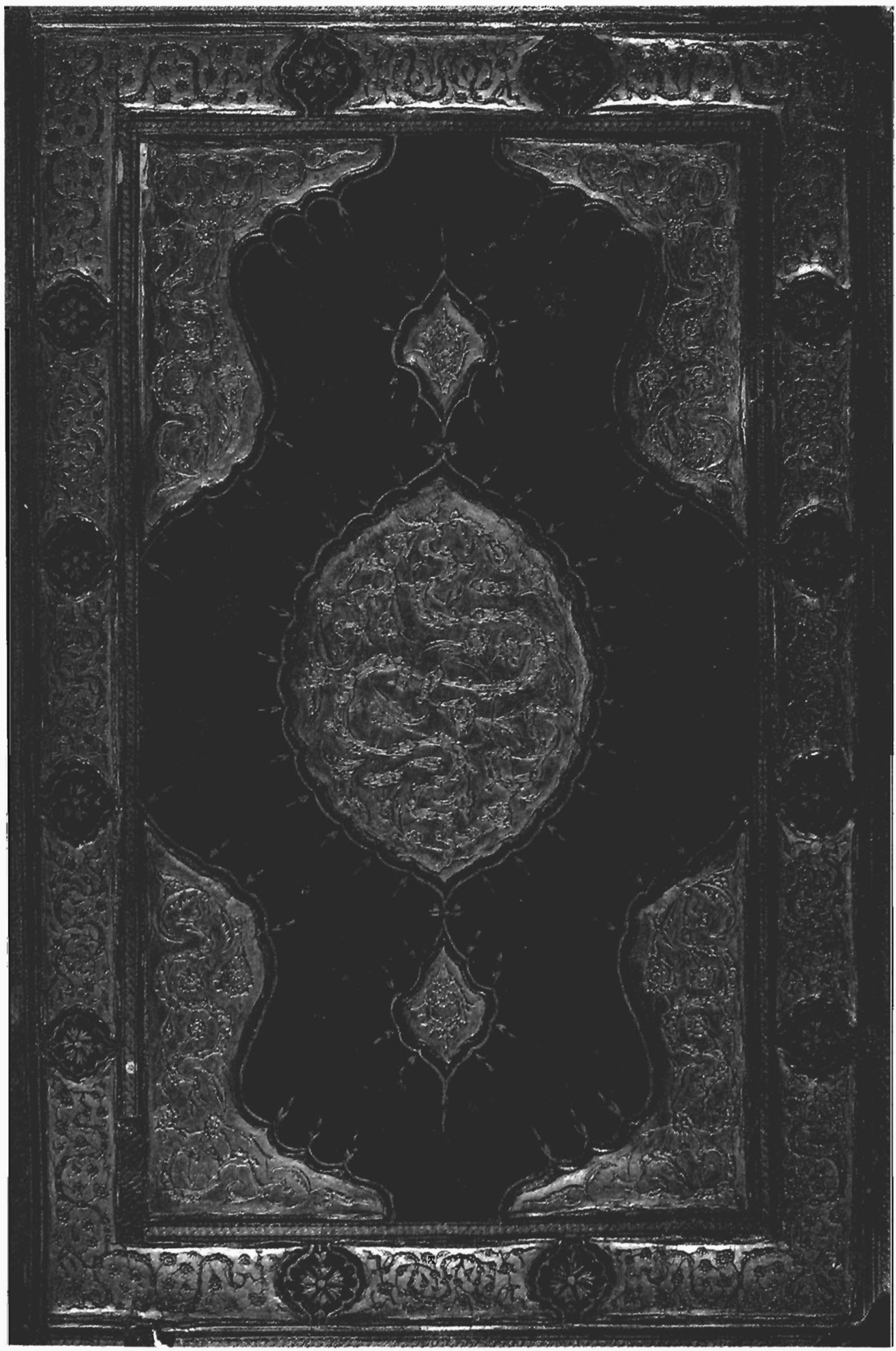

Figure 1. Codex 4, f. $112 a$. 
A Collection of Qur'anic Codices

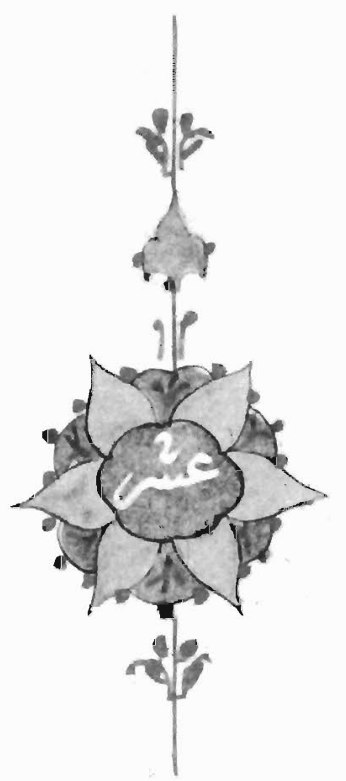

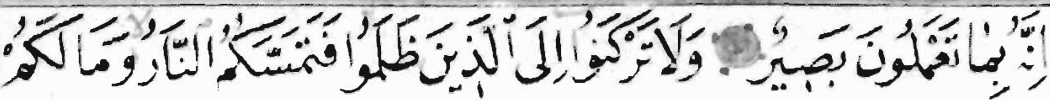

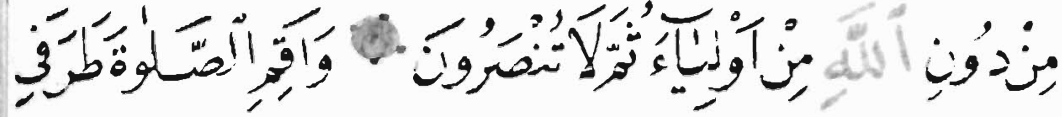

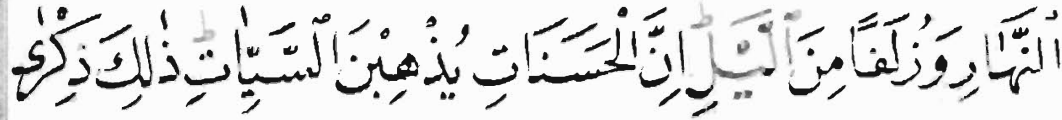

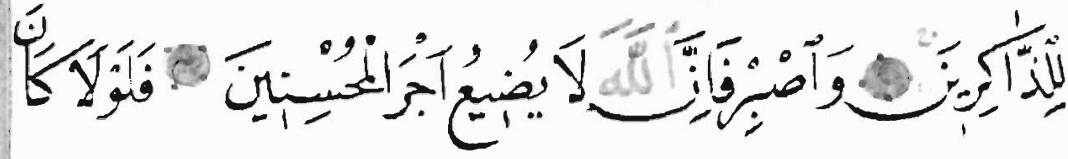

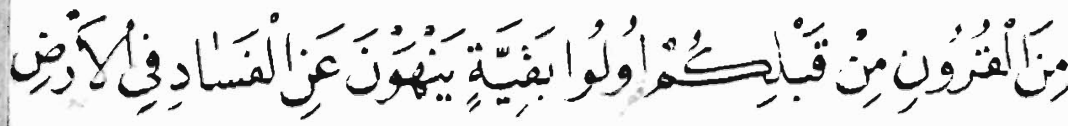

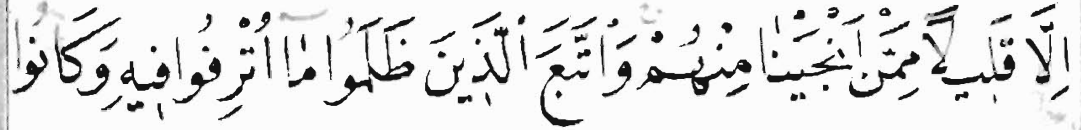

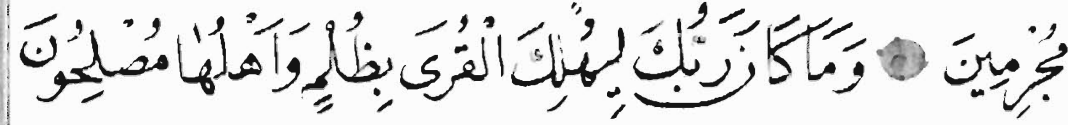

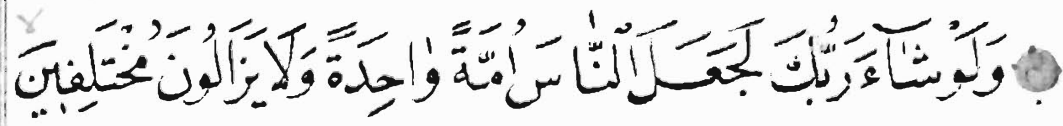

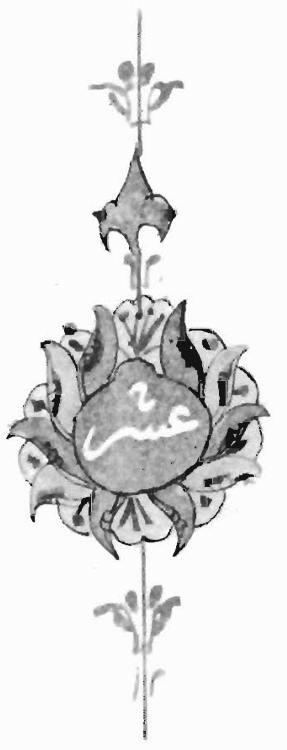

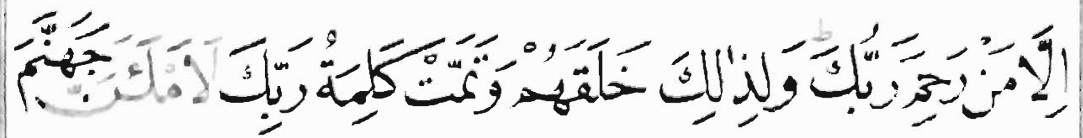

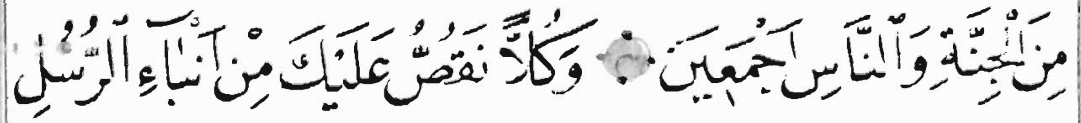

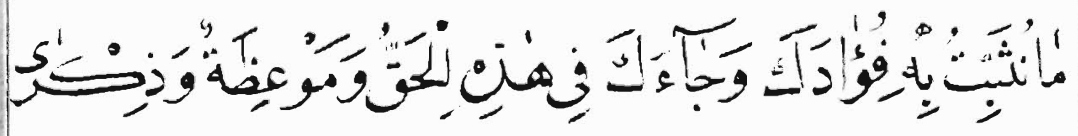

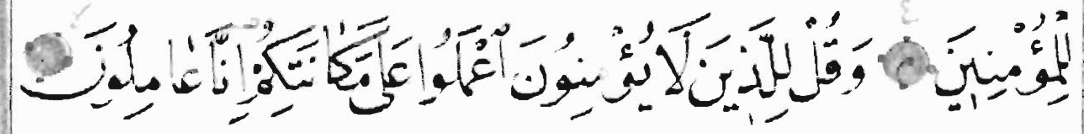

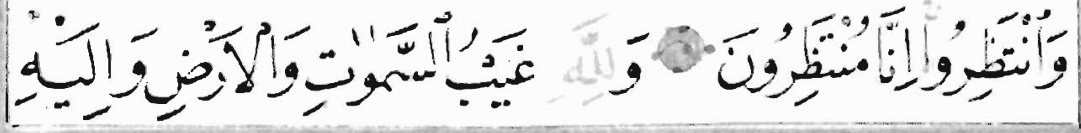

Figure 2. Codex 4 . 
A Collection of $Q u r^{\prime} a n i c$ Codices

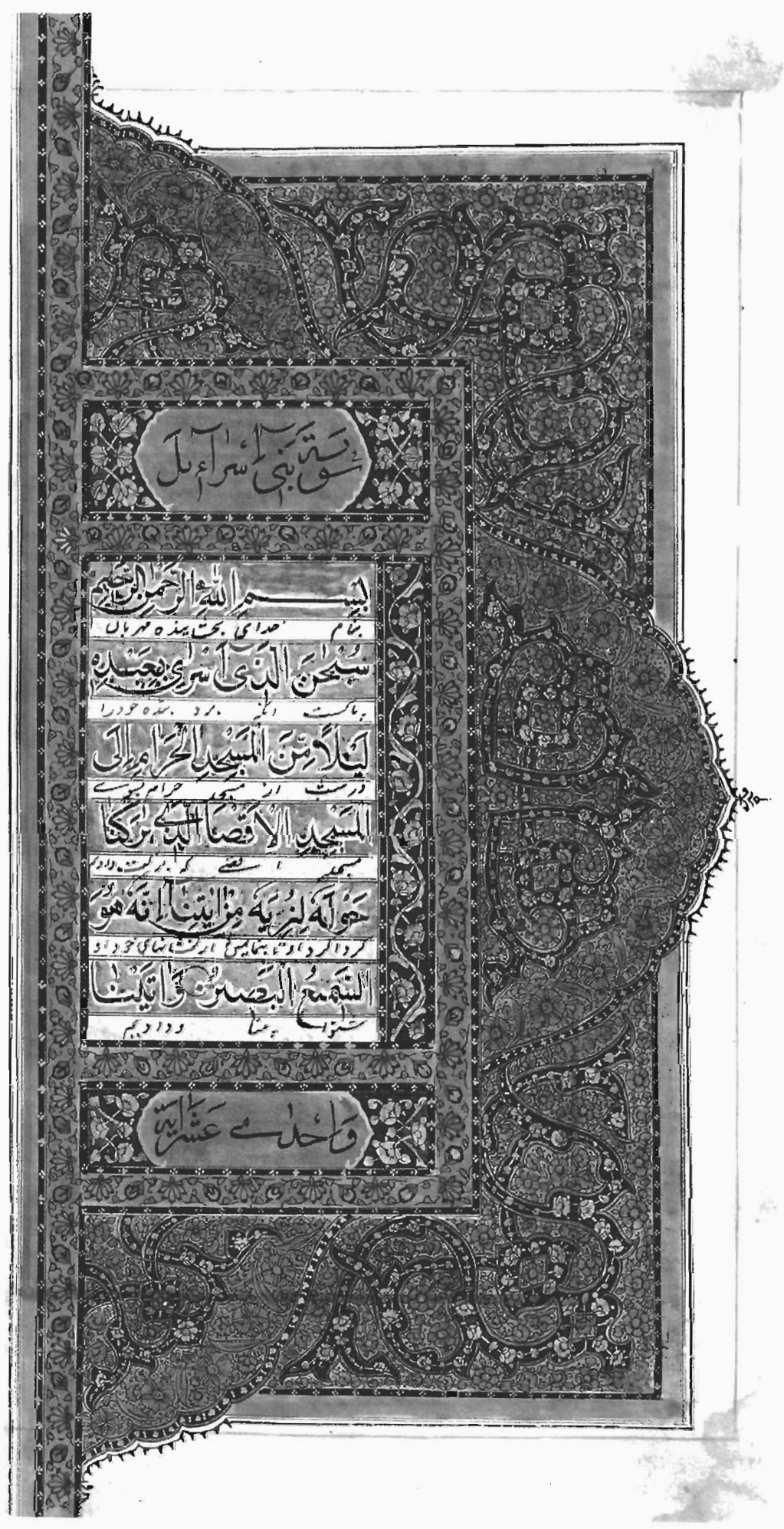

Figure 3. Codex 5, f. 184b. 
A Collection of Qurianic Codices

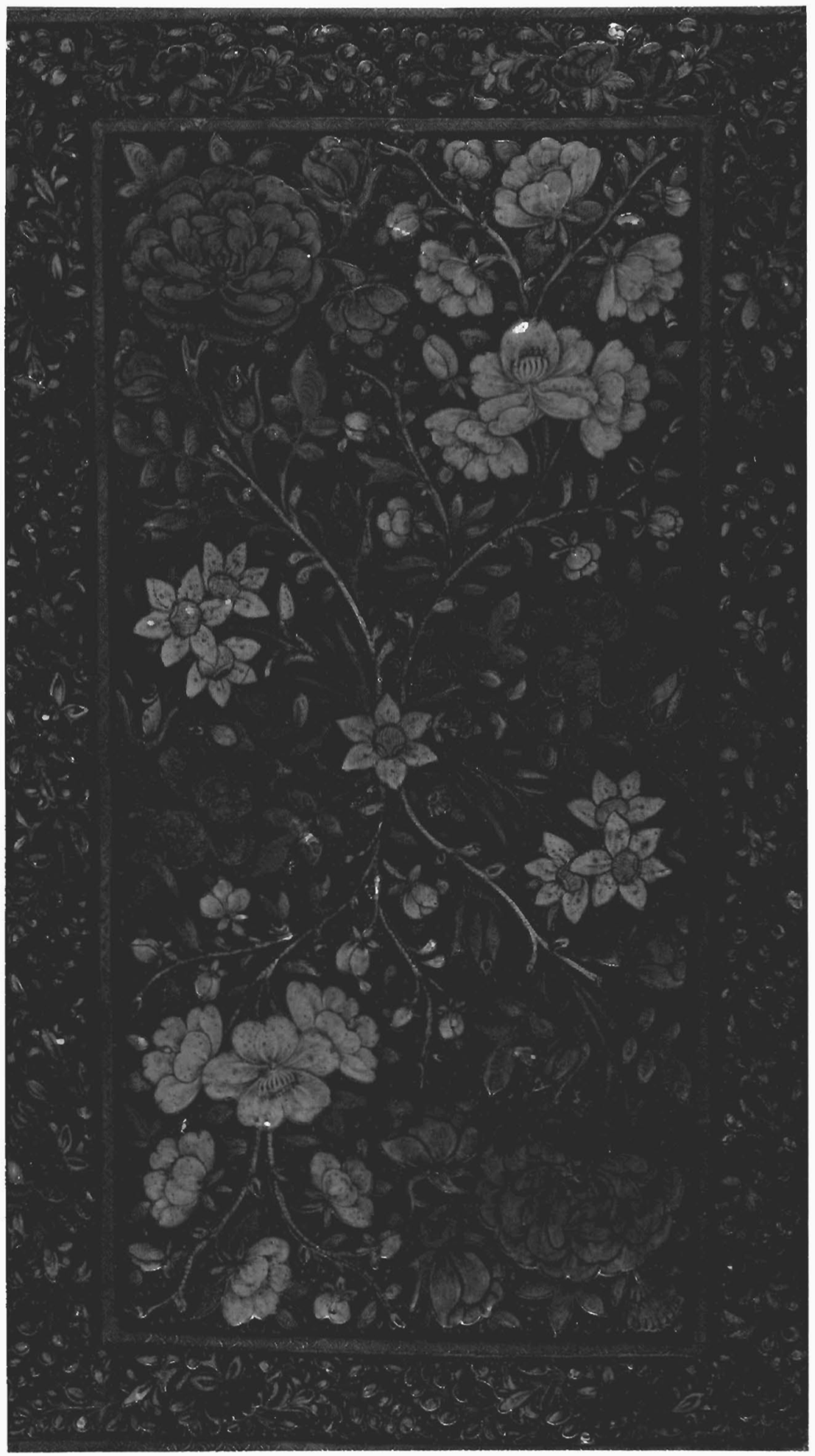

Figure 4. Codex 5. 
A Collection of Qur'anic Codices

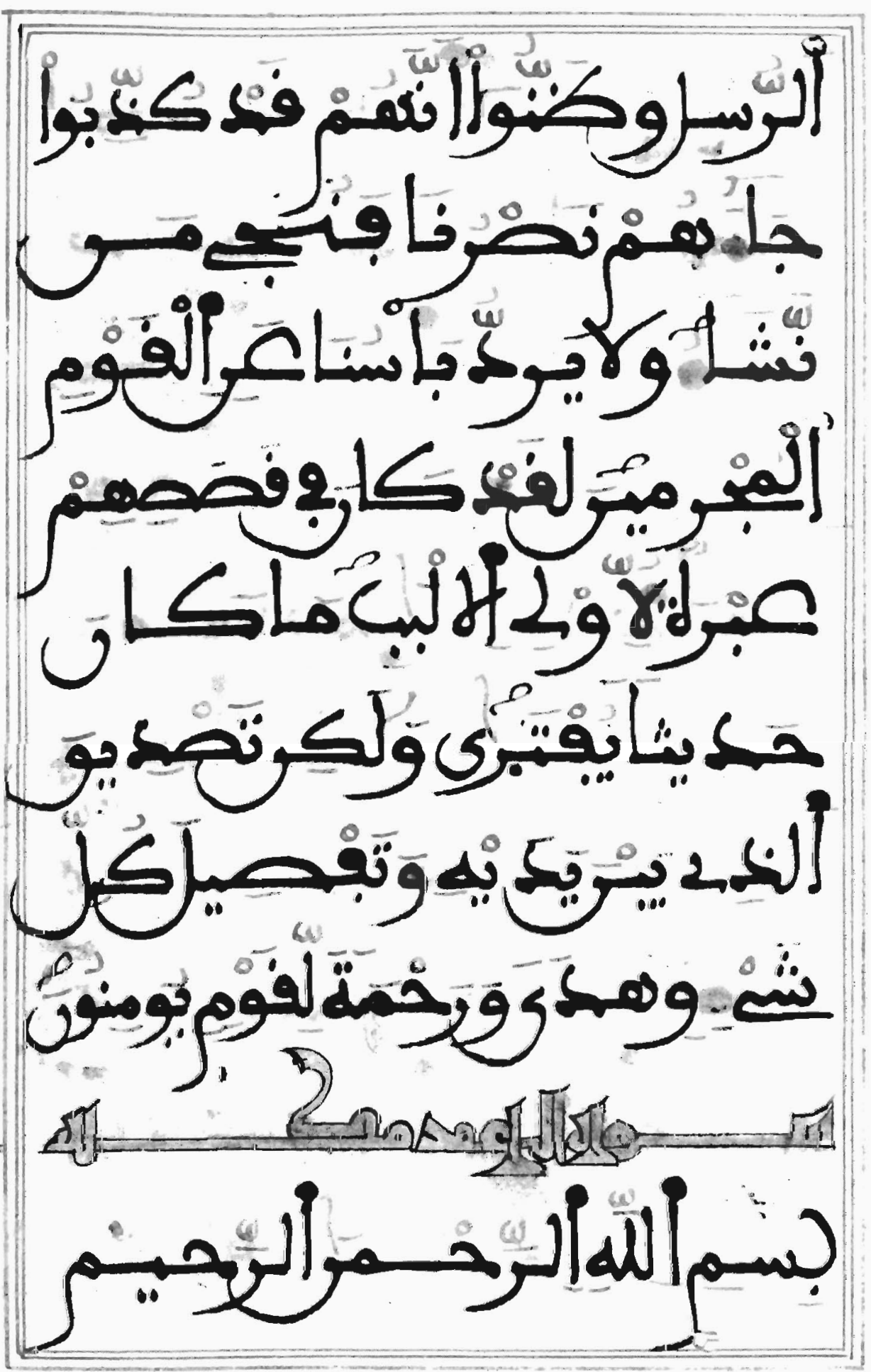

Figure 5. Codex 6, f.66a. 


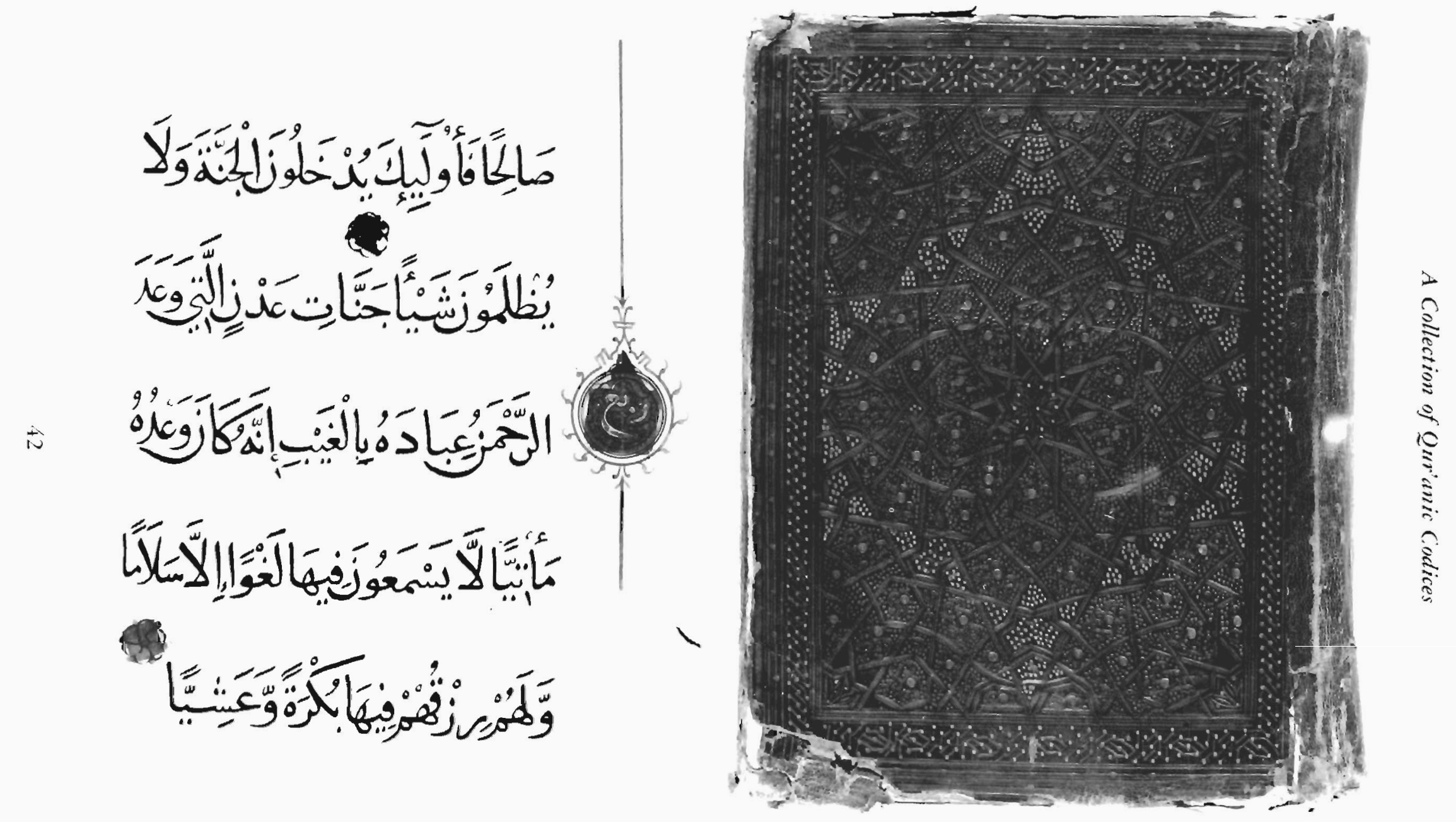

Figure 6. Codex 7, f.17b and binding. 
A Collection of Quranic Codices

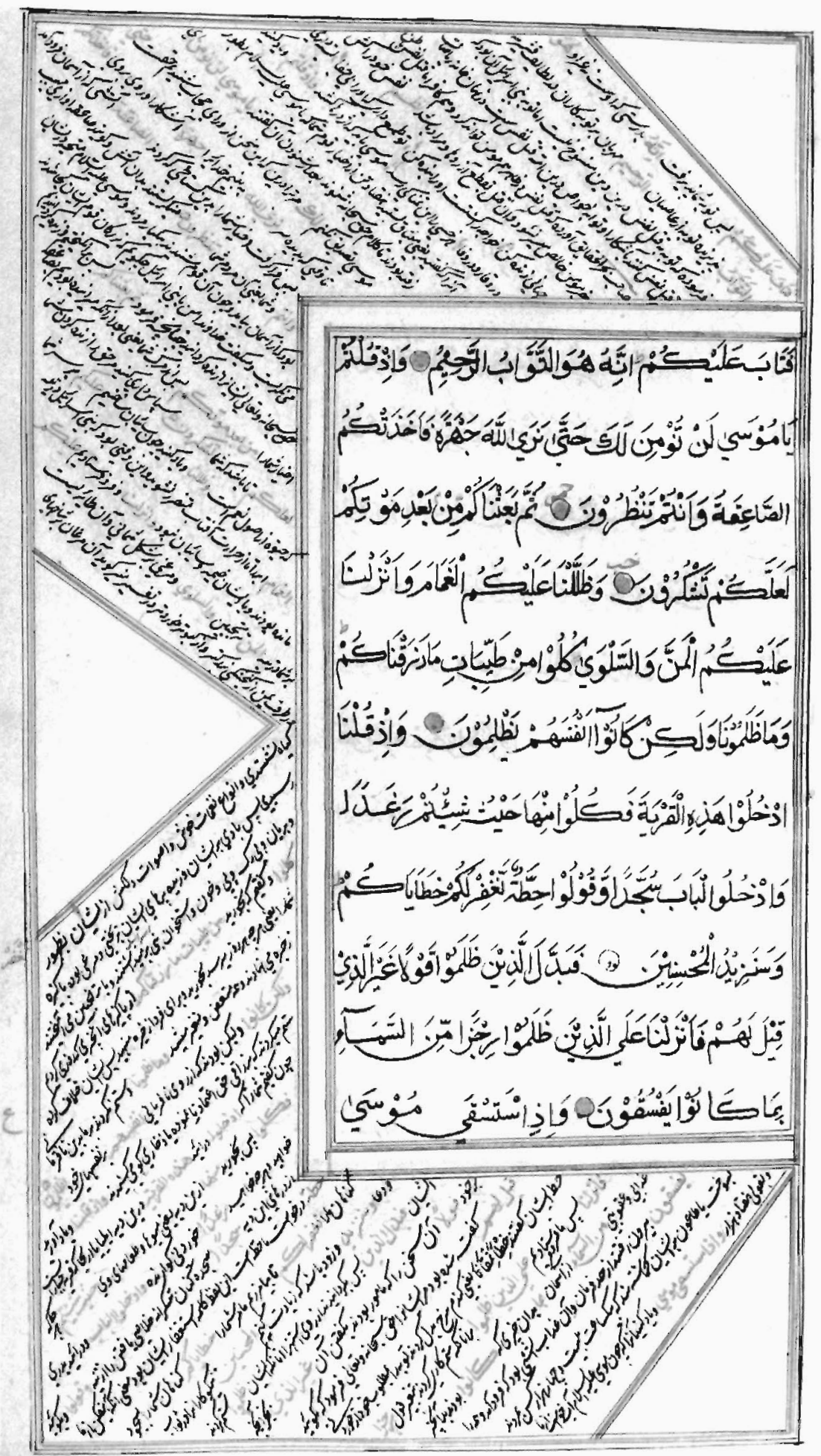

Figure 7. Codex 11, f.6a. 


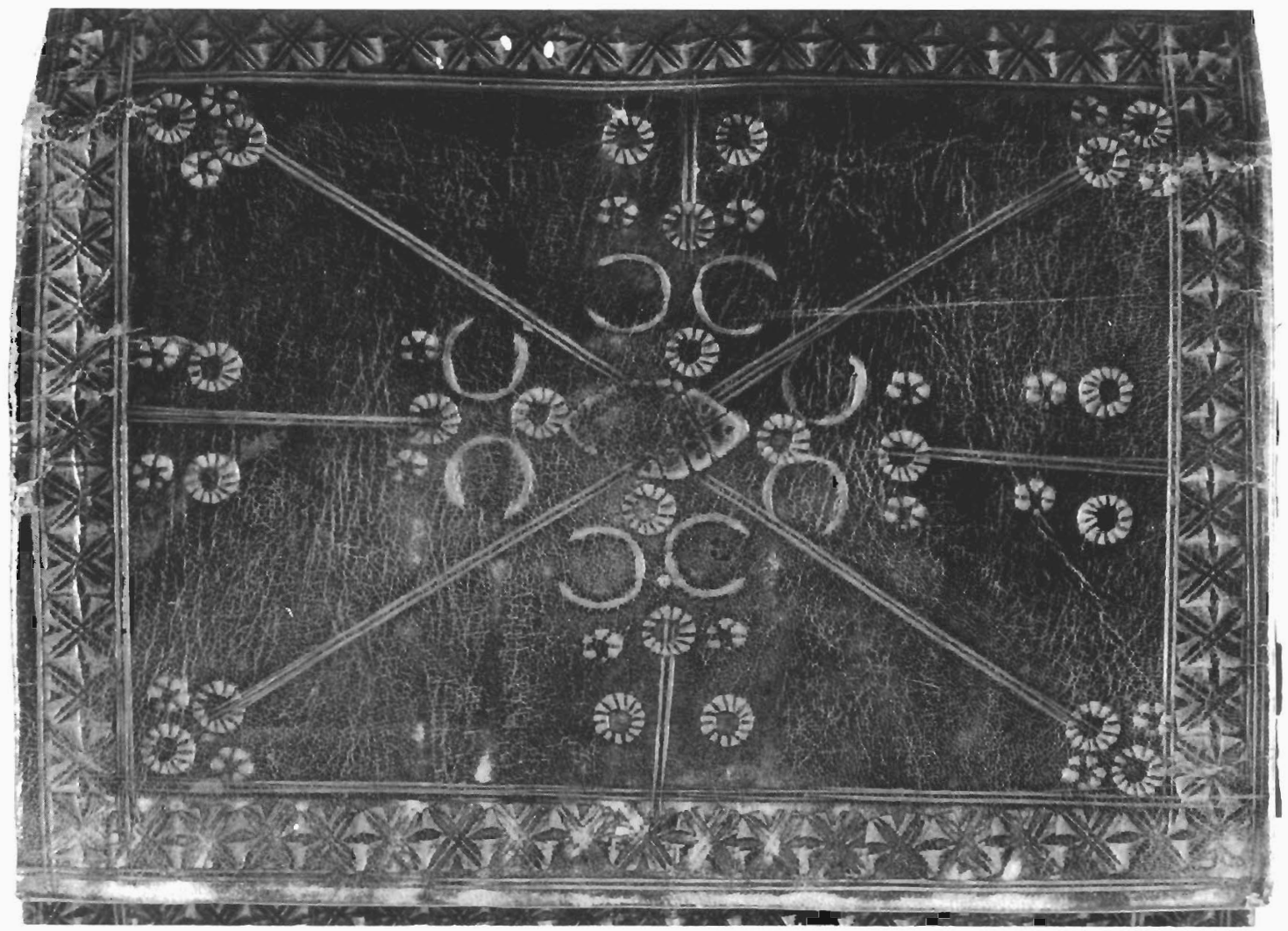

0
0
0
0
0
0
0
0
0
0
0
0
0
0
0
0
0
0
0
0
0
0

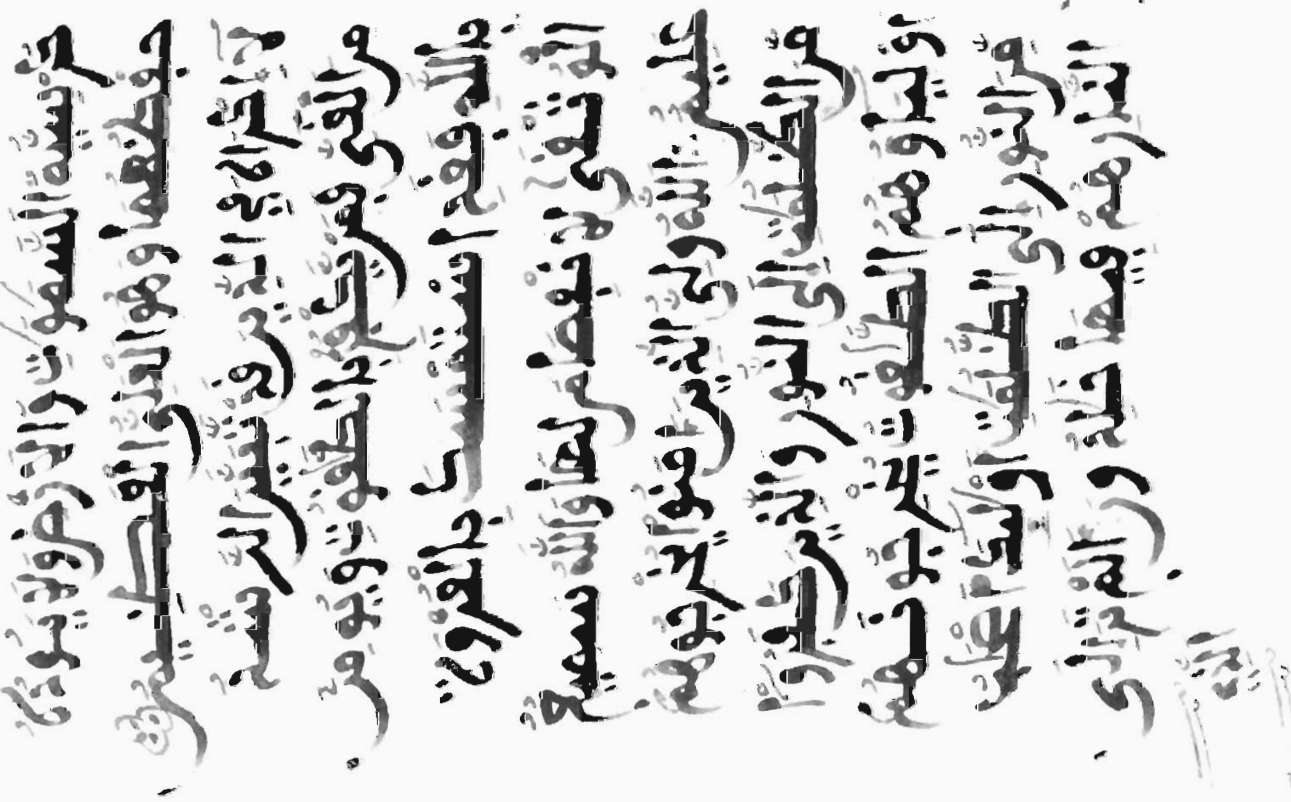


A Collection of Qur'anic Codices

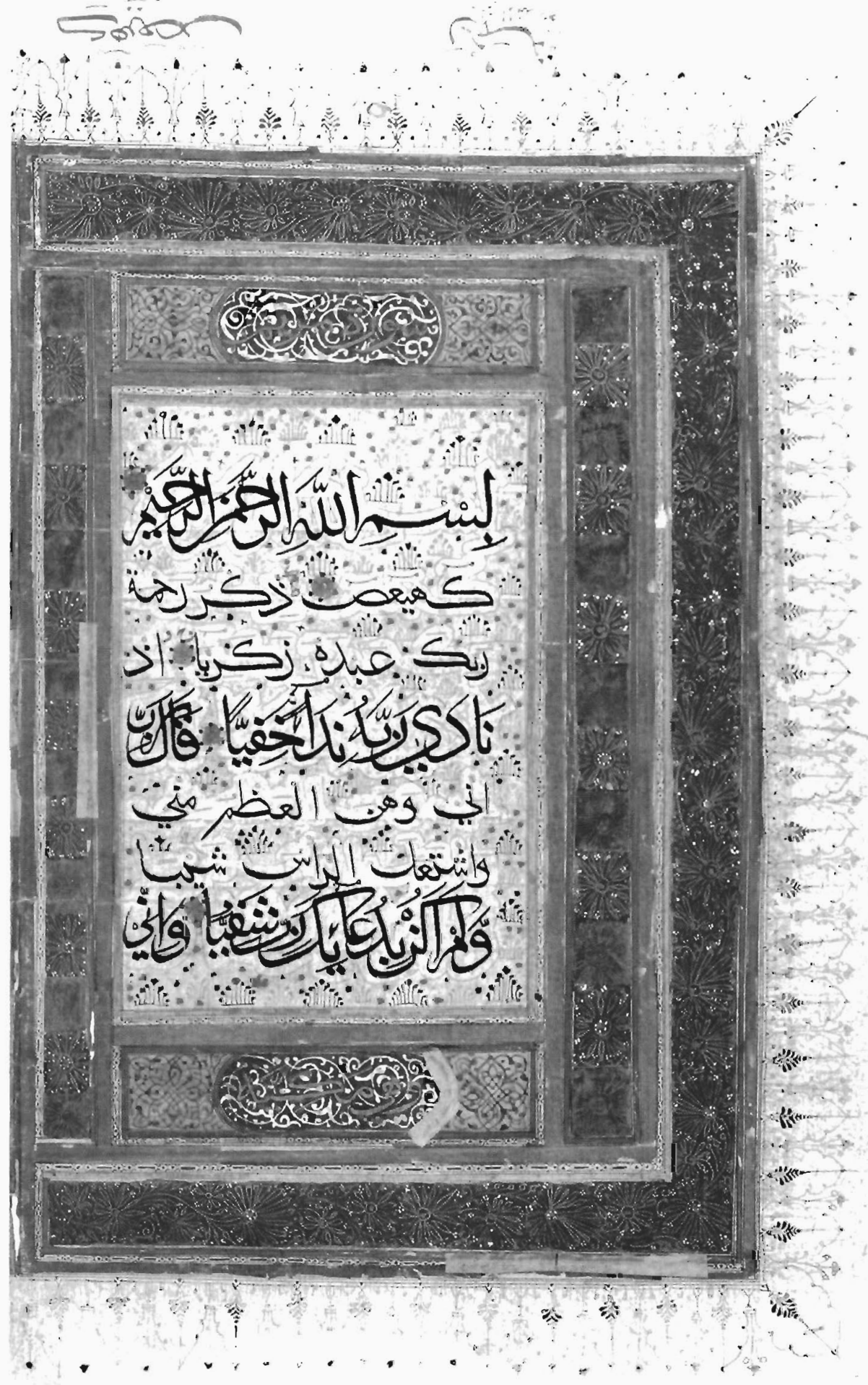

Figure 9. Codex 14, f. $217 \mathrm{~b}$. 


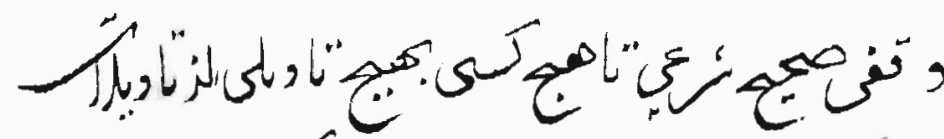

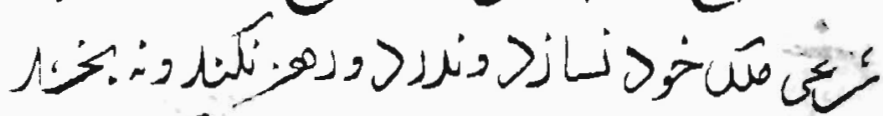

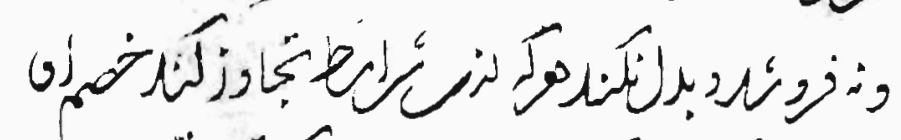
فا

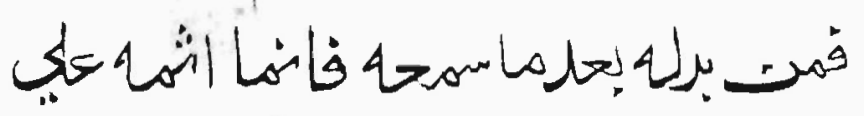

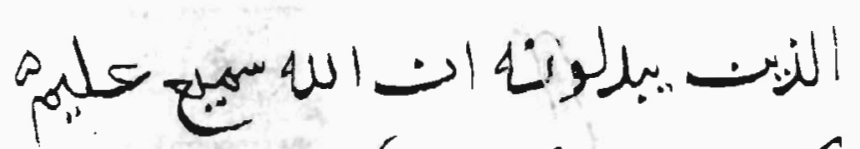

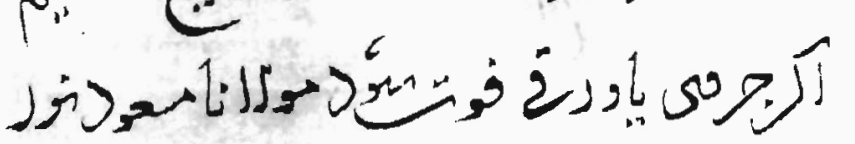

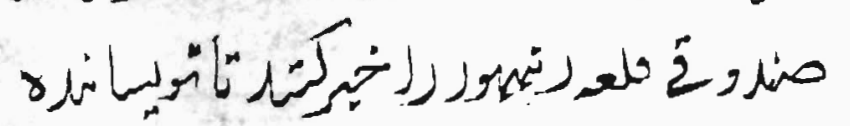

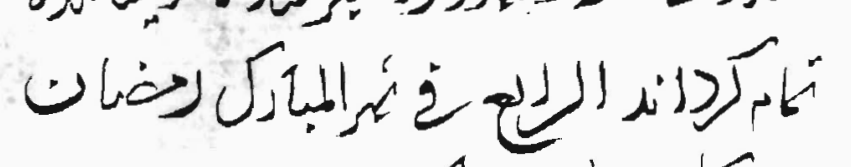

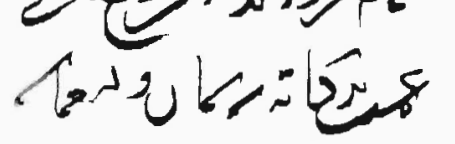

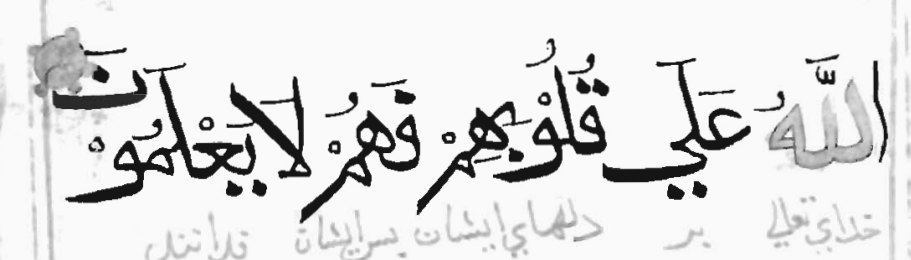

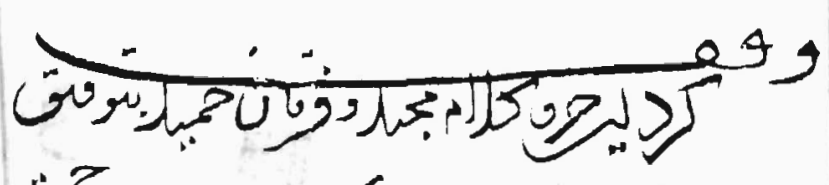

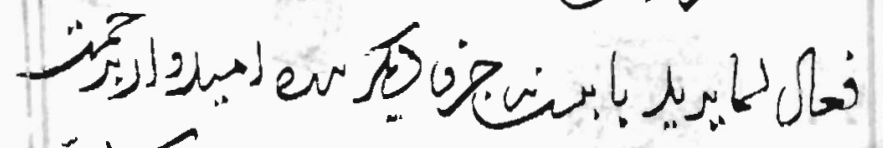
.

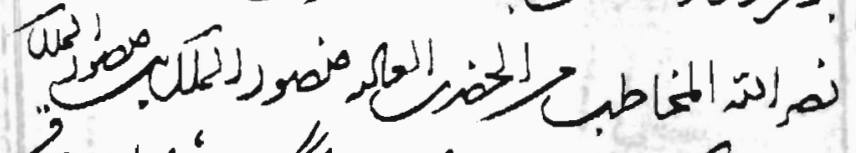

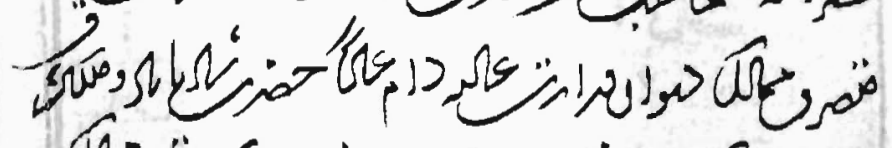

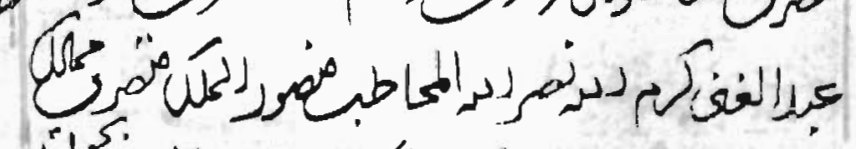
ilsis

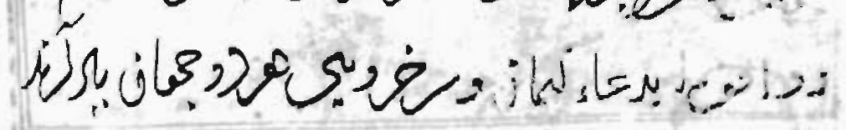

Figure 10. Codex 16, ff. $42 \mathrm{~b}-43 \mathrm{a}$ 


\section{A Collection of Qur'anic Codices}

Turkish school, is often hooked. Furthermore, the alif of Naskh (when forming part of the definite article) is in the overwhelming number of cases devoid of tarwîs. The use of tarwis on other letters (mainly the alif in the lâm alif, initial lam and $t \hat{a}$ ) in this script or alter natively its complete absence may be indicative of schools of calligraphy or the individual styles of scribes and calligraphers. This is the case e.g. with the Mamluk Naskh, which, to judge from extant specimens, is executed without tarwis. It could also be that an unsystematic use of tarwis in Naskh is a result of carelesness on the part of the calligrapher.

\section{DESCRIPTION OF THE CODICES}

\section{1 (A16)}

ff. [302], $177 \times 110 / 123 \times 68 \mathrm{~mm} ., 15$ lines per page. Written on European laid paper (watermark: crown and grapes; GAVLAC). Fully vocalized Naskh script in black with recitation marks in red ink and chapter headings in white on gold background. This hand uses a small hooked tarwîs (characteristic of Turkish hands) on the lâm (going to the right) and alif in lâm alif al-warrâqûyah (descending to the left). The codex opens with a rubbed double frontispiece. The text is enclosed in a golden frame and is divided by means of gold discs. The margins carry floral medallions, the words bizb and 'ashr, as well as some corrections. Bound in dark-red morocco with onlaid centre medallions, pendants and corner pieces. Executed by 'Abd Allâh ibn 'Abd al-Rahmân, a pupil of Râsim Muhammad Afandî̀ in 1154 i.e. 1741-2.

\section{2 (A17)}

ff.[153], $175 \times 112 / 135 \times 74$ mm., 30 lines per page. Written on European laid paper (watermark: lion passant guardant; C N A and I M C?). The text is written in a very small, fully vocalized Naskh hand in black ink, arranged into two medallions per page within a rectangular panel. This hand is characterized by the unsystematic use of tarwis. The volume opens with an illuminated double page frontispiece, now rubbed and damaged. Numerous floral designs in the margins. The margins also carry a number of corrections and the word bizb. Bound in dark-red morocco with onlaid centre medallions and corner pieces. Executed by Muhammad al-Hilmî, a pupil of Muhammad al-Alâ'î Muhammad 'Abd Allâh, in 1240 i.e. 1824-5. According to the colophon, this is the sixth copy of the Qur'an executed by his hand.

\section{$3(\mathrm{~A} 18)$}

ff. $[\mathrm{i}, 305], 197 \times 122 / 135 \times 70 \mathrm{~mm} ., 15$ lines per page. Written on European glazed wove paper of biscuit tincture in a fully vocalized Naskh hand. The tarwîs occurs only on the letter alif of the lâm alif al-warrâqîyab and points to the left. The main text is executed in black ink; recitation marks in red and chapter (sîrah) headings in white on imitation gold background. The codex opens with a richly illuminated double frontispiece characterized by a floral design. Floral designs are also used for marginal medallions. There are in all fortythree of these medallions. The marginal marks indicating the division of the text are not indicated. Bound in red morocco, the main panel consists of a pattern of dots. This codex is the work of Hâfiz Ahmad Hilmî, a pupil of Muhammad al-Hamdî, known as Nafs al-Bakbâzârî̀ Bawâsh zâda (thus), who executed it (kataba) in 1284, i.e. 1867-8. This is the fifth copy of the Qur'an (mushaf) executed by his hand (see tasdî, f. 305a).

Purchased from Dr. Patton in June 1929.

4 (A19) Figures 1 and 2

ff.[309], $267 \times 180 / 190 \times 110 \mathrm{~mm} ., 13$ lines per page. Written on thickish non-European laid paper of biscuit colour, characterized by wavy laid lines. Fully vocalized Naskh hand with the word Allab in gold and recitation marks in red ink. This hand is generally devoid of tarwis except in the case of lam alif al-warrâqîyab where it occurs on the alif and points to the left. The codex opens with an illuminated double frontispiece. The text is enclosed in a golden frame and blue ruleborders. Surah-headings are executed in white on gold background and enclosed in illuminated headpieces. The text division into $j u z$ ', bizb, and 'ashr is shown by means of illuminated marginal medallions. Bound in darkbrown morocco with blind-stamped panels, medallions and pendants filled with arabesque designs. The stamped surfaces are brushed 


\section{A Collection of Qur'anic Codices}

with gilt. The spine is broken and the flap wanting. This manuscript was executed by Husayn ibn 'Alî al-Amâsî, Imam of the Abû al-Fath Sult ân Muhammad Khân (Mehmet the Conqueror) Mosque in Rabî II, 1072 (date given in Turkish) i.e. 1661. This is the 22nd copy of the Qur'an executed by his hand. Folio la contains a bequest (waqf) note addressed to al-Sayyidah Hanîfah, daughter of a certain 'Alî Bâshâ, dated 15 Jumâdá I 1237 i.e. 1822.

\section{5 (A20) Figures 3 and 4}

ff. [409], $286 \times 167 / 286 \times 157 \mathrm{~mm} ., 13$ lines per page. Written on fine, glossy and creamcoloured non-European paper having dense and regular laid lines. Fully vocalized Western Indian Naskh hand with an interlinear Persian translation in Nasta'lîq. The Naskh hand has no tarwîs on alif and lâm, except in the lâm alif al-warrâqiyah, where it protrudes to the left. The Qur'anic text is in black and the translation in red ink. The codex opens with a superbly illuminated double frontispiece executed in Kashmiri style. Similar doublepage illumination can be seen on ff. $184 \mathrm{~b}-185 \mathrm{a}$ and $408 \mathrm{~b}-409 \mathrm{a}$. The text is enclosed in a golden frame with inner and outer deep-blue rules. Sürab-headings are enclosed in rectangular headpieces and executed in deep-blue ink on gold background. An additional outer frame is provided for marginal decorations and comments. Here we find $j u z^{\prime}$-numbering and short versions of sîrab-headings placed in corners. Other elements include illuminated medallions and the markings 'ayn, thalathab, $n u b^{\prime}, n$ isf and sajdab. Bound in very elegant lacquer covers without flap. The central panel of the upper and lower covers consists of an intricate flower design, featuring, among others, dahlias and apple blossoms. Executed (calligraphed and illuminated) in Haydarâbâd between 1282/1865-6 and 1289/1872-3. The first date appears at the end of the text and therefore is likely to be associated with the copying and the second one appears in the statement on f.409b in the statement: nivishtab shud dar farkbundab-i bunyâd-i Haydarabâd dar sanab 1289.

Purchased from Meyers and Co. Ltd. in 1943 and presented to the library by Lady Roddick.

\section{6 (A21) Figure 5}

ff. $[70], 235 \times 165 / 180 \times 114 \mathrm{~mm} ., 10$ lines per page. Written on thick European laid paper (watermark: anchor, B-see e.g. ff, 40, 44). Bold, fully vocalized Maghribî hand with bamzab indicated by a yellow dot, tashdid and sukin in blue and fatbah, kasrah, dammah and alif of prolongation in red. The final $f \hat{a}$ ', qâf and $n \hat{u} n$ are not pointed. The text begins with an illuminated headpiece containing al-isti'âdbah (an invocation against Satan: a'ûdbu bi-Allâh min al-shaytân al-rajîm) and is followed by v.93 of ch.9 (S) urat al-Tawbab). It ends with v. 18 , ch. 13 (Sûrat al-Ra'd), followed by the tasdiq (sadaqa Allâh al-'Axîm) and colophon. The text is enclosed in one blue and two red rules. The sitrab-headings are written in gold in either Maghribî or ornamental "Kufi" scripts and marked out by means of marginal palmettes (there are no surrounding panels). The same applies to the words bizb, $r u b^{\prime}$ and nisf written in the margins. A round medallion is used for the word bizb on ff. $15 \mathrm{a}$, $29 \mathrm{a}, 41 \mathrm{~b}$ and 56b. Another medallion of conic shape is used for the word sajdab (f. 69b). Bound in red morocco with simple blind tooling and onlaid medallions. The name of the calligrapher is not given. According to the colophon this is Volume (juz') 5 of a set (tajzi'ab) of 12 volumes executed in 1144/1731.

Purchased from Miss Fisher in 1927.

\section{7 (A22) Figure 6}

ff. [46], $210 \times 164 / 150 \times 105 \mathrm{~mm}$., 5 lines per page. Written on thick laid Mamluk paper characterized by the existence of chain lines grouped in threes and running obliquely across the face of the page. The distance between the chain lines is ca. $10 \mathrm{~mm}$. and 45 $\mathrm{mm}$. between each group. Executed in fully vocalized al-Naskh al-Faḍâh hand, the main characteristics of which are the complete lack of tarwis, the systematic use of lâm alif al-warrâqiyah, and the height of the alif being $9-10 \mathrm{~mm}$. The main text is in black ink whereas the surab-headings are executed in gold outlined in black (ff.9a, 23b) in the form of Tawqî' script, similar to the one used by Ibn al-Wahîd (see D. James, Qur'ans of the Mamliuks. London, 1988, pp. 35-65.). 


\section{A Collection of Qur'anic Codices}

The verses of the Qur'an are divided by means of gold florettes. The codex begins with an illumination on the recto of the first folio consisting of a panel divided into a cartouche and a multi-lobed medallion carrying an inscription: al-sâdis 'ashar min al-rab'ab al-sharîfah nafa'a Allâb bibâ. This inscription tells us that this is the sixteenth volume of the Qur'an out of most probably a set of thirty volumes. It contains v.72, ch. 18 (Sûrat al-Kahf) through ch.20 (Sûrat Tâ Hâ). The end is marked by a large circle (shamsab) with the inscription in decorative "Kufi": kbitâmubu misk (perhaps the equivalent of "finis coronat opus" or "the crowning touch"). The predominant colours used in the decoration are gold and lapis lazuli.

Other illuminations include round medallions in the margins with the words hizb, nisf, rub', sajdab. The volume is marked throughout as wagf and a badly rubbed inscription on the recto of the first folio reads: maqarrubu bi-alBarqûqîyah bi-al-Sabrâ, referring to al-Khânaqâh al-Barqû́qîyah in the desert i.e. extra muros, an institution built for the Mamluk Sultan Barqûq by his son Faraj (d.815/1412), where the present copy was deposited. Bound in dark-brown leather, blind-tooled with gold dots. The centre panel consists of a typical Mamluk decoration with a ten-pointed star in the centre and a pattern of interlacings. The doublures are of blocked pressed leather. The front cover is now detached and damaged. The calligrapher of this manuscript is not known despite the statement on the last folio written in a clumsy hand attributing the work to Ibn Muqlah (d.328/940) (barrarabu Ibn Muqlab al-Wazîr al-A'zam!). The date is also not given. However, on the strength of the evidence which we have before us it is likely to have been executed in the $8 / 14$ th century.

Purchased from H. Khan Monif, New York. 8 (A23)

ff.506, $106 \times 95 / 80 \times 60 \mathrm{~mm}, 17$ lines per page. Written on brown non-European paper having faint laid lines sometimes completely disappearing, giving the appearance of wove paper. Fully vocalized small Bihârî script (without tarwîs) using black and red ink. The text is enclosed in one blue and two red rules.
The text begins with a double page, bearing somewhat simple illumination. The same double page illumination is repeated on ff. $121 \mathrm{~b}-122 \mathrm{a}, 248 \mathrm{~b}-249 \mathrm{a}$ and 374b-375a. Other illuminations include medallions with the word juz'. The surab-headings and recitation marks are written in red and so are the words such as nisf, rub', sajdah, thalatthat arba $\hat{a}^{\prime}$ and the letter 'ayn indicating the division of the text. The margins also carry some corrections and explanations in Persian, a number of which are headed by what appears to be the word fasl or the abbreviation of fa'idat al-asl (cf. no.12). Bound in recent brown leather binding without flap. Copy anonymous and undated. Most probably 10/16th century or later.

Purchased from H. Khan Monif in 1928.

9 (A24)

pp. $708,150 \times 103 / 105 \times 55 \mathrm{~mm} ., 13$ lines per page. Written on laid European paper (watermarks: 1. a cross-bow; trefoil B A 2. pascal lamb; trefoil C B 3. anchor in a circle; trefoil C B).

Copied by two Naskh-based hands, the second being very cursive and characterized by a pronounced tilt to the right. Rule-borders, sûrabheadings and round dots are executed in red. Bound in dark-brown morocco with blindstamped central medallions. Anonymous and undated copy. Probably mid 13/19th century. The last sîrah is followed by a comment in Ottoman Turkish on the mystical significance of the Arabic letters.

\section{$10($ A25)}

ff. [466], $300 \times 215 / 218 \times 120 \mathrm{~mm}$., 11 lines per page. Written on brown, non-European paper of wove texture and very flocculent. Fully vocalized Naskh hand, using tarwîs only on the alif of the lâm alif al-warrâquab. Surab-headings and recitation marks in red ink. The text is enclosed in two red and one blue rules. The margins carry marks relating to the division of the text such as juz', sajdab, nisf, rub', thalatbat arba' and the letter 'ayn. This copy is anonymous and undated; probably late $12 / 18$ th or $13 / 19$ th century. The main text is followed by a prayer for the Prophet Muhammad in the form of a poem (forty 


\section{A Collection of Qur'anic Codices}

verses) beginning: al-salâb wa-al-salâm 'alayka yâ rasul Allâb. The recto of the first folio has an invocation yâ kabikaj and two unintelligible notes. Bound in light-brown morocco with onlaid medallions.

Purchased in 1922 for $\$ 25.00$ from C. Bryant of the 2nd Queen's Regiment, who obtained it in 1897 at Tirah on the North-Western Indian frontier.

\section{1 (A26) Figure 7}

ff. $[415], 345 \times 215 / 303 \times 165 \mathrm{~mm}, 11$ lines per page. Written on glossy, creamy nonEuropean paper characterized by very fine laid lines, sometimes almost invisible. Fully vocalized Naskh hand (using tarwîs only occasionally and unsystematically), with surabheadings and recitation marks in red ink. At the beginning and the end of the codex there are eighteen and twenty blank end-papers. The Qur'anic text opens with a double-page illumination in gold, blue and dark-red. The pages are divided into two major panels: the inner carrying the text of the Qur'an and the outer filled with a commentary in Persian by Kamâl al-Dîn Husayn Kâshifî Sabzavârî (d.910/1504-5) and entitled Mavâbib-i 'aliyab (published in Tehran 1317-29 A.H.). The commentary is transcribed obliquely in an elegant Nasta'lîq hand. The margins carry marks relating to the textual division of the Qur'an such as juz', nisf, rub', thalâthat arbá $\hat{a}^{\prime}$ as well as corrections and short comments. Bound in dark-brown morocco with blind-stamped medallions and panels brushed with gilt. The front cover is now detached. No date of copying or name of scribe is given; probably $12 / 18$ th century.

\section{2 (A27)}

ff. [517], $315 \times 228 / 242 \times 157 \mathrm{~mm}$., 9 lines per page. Written on biscuit colour, fine nonEuropean paper having fairly regular laid lines. Fully vocalized Naskh-based hand with an interlinear Urdu translation in Nasta'lî. One of the characteristic features of this hand is the use, though somewhat unsystematic, of tarwis on the alif and lam, protruding to the left. The Qur'anic text is in black and the translation in red ink. The text is enclosed in a golden frame with red and blue rules on each side and the sûrab-headings are executed in red or white on either a plain or golden background. Polychrome illumination is also used for the division of the text (juz', nisf, rub', thuluth, saj$d a b)$. Marginal annotations in Urdu are headed by the letter $f \hat{a}$ ' (initial form) or $f \hat{a}$ ' and $s \hat{a} d$ (initial, suspended form), the latter written above the elongated horizontal stroke of the $f \hat{a}^{\prime}$. The letter șâd is also used to indicate the end of the marginal note. These letters most probably represent the words fa'idab (note) and asl (original text, i.e. the text enclosed in the central panel), being part of the original expression fâ'idat al-asl (cf.no. 8). A note on f. la-b tells us that the translation is by 'Abd al-Qâdir, son of Walî Allâh ibn 'Abd al-Rahîm Muhaddith Dihlavî, and made in $120 \dot{5} / 1790-91$. The present copy is not dated, but is likely to have been executed either in 1205 or shortly afterwards. It is bound in red morocco with onlaid medallions, pendants and corner pieces (flap missing).

\section{3 (A28) Figure 8}

ff. [ca.300], $215 \times 165 / 160 \times 105 \mathrm{~mm} ., 11$ lines per page. Written on brown wove European paper. Fully vocalized African (Sûdânî) hand using brown ink. The characteristic feature of this hand is the existence of a tarwîs on the alif and lâm, projecting in most cases to the right but sometimes to the left, as well as the 'tail' on the alif of prolongation. The final $n \hat{u} n$ and $q \hat{a} f$ are not dotted, but the $f \hat{a}^{\prime}$ is. The folios are loose and in disorder. Simple decoration can be found on the first and last folios. Additionally, the word bizb is enclosed in a circular medallion divided into eight compartments and an inner circle. Other textual divisions include nisf, rub', thumn and sajdab. The margins carry a number of corrections marked with the letter $k b a^{\prime}$ (initial form) superscript and the placet (sabba) situated at the end of the correction. The verses are separated by means of three dots arranged in the shape of a triangle and sometimes outlined to give it the shape of a three-petalled florette. The copy is anonymous and undated ( mid 13/19th century). The loose folios are protected by a blind-stamped, red morocco casing with a thong attached to the extreme end of the envelope flap.

Purchased from H. Khan Monif in 1942. 


\section{A Collection of Qur'anic Codices}

\section{4 (A29) Figure 9}

ff.[439], $575 \times 325 / 360 \times 210 \mathrm{~mm}$., 15 lines per page. Written on non-European paper of biscuit colour and having fine and regular laid lines. Executed in a large, fully vocalized Bihârî hand with the initial, median and final lines in a thicker and larger script of Thuluth type (the height of alif being $30 \mathrm{~mm}$.), with a systematic use of tarwiss, descending to the right. The Bihârî hand is entirely devoid of tarwîs. The volume begins with a double-page illumination containing five empty medallions per page. This is followed by another doublepage illumination containing the opening verses of the Qur'an. Other double-page frontispieces are located on ff. $105 \mathrm{~b}-106 \mathrm{a}$, $217 \mathrm{~b}-218 \mathrm{a}$ and $324 \mathrm{~b}-325 \mathrm{a}$. Among the illuminated pieces are medallions carrying the words juz', rub', nisf, thalatthat arba $\hat{a}^{\prime}$ and sajdab, as well as $s \hat{u} r a b$-headings and the word Allâh. The main text is enclosed in a ruled panel and surrounded by two outer panels, the first containing selected key words written in red and blue and the other glosses in Persian arranged in a zigzag form. The main text is followed by a Persian commentary on Surat al-Fâtibah and Fâl-i Mushaf, a divinatory poem (also in Persian) consisting of 193 verses and divided by means of the letters of the alphabet into groups of six or seven dîu bayt. Bound in lacquer covers with simple decoration consisting of a central medallion and floral decoration in the corners and border. This copy is anonymous and undated; probably 10/16th century or earlier.

Purchased from H.K. Monif.

15 (A30)

ff. $85,225 \times 135 / 154 \times 85 \mathrm{~mm}$., 7 lines per page. Written on brown non-European paper characterized by wavy and thick laid lines, sometimes not easily visible. Fully vocalized Bihârî hand (using occasionally right-sloping tarwîs) in black ink and surab-headings, the word Allâh and the interlinear Persian translation in red ink. There is no textual division except for the letter 'ayn. The present codex is acephalous and contains a selection of short chapters beginning with Sûrat Yâ Sîn (36) and ending with Sûrat al-Nâs (114). Bound in a recent red morocco of European style (without flap). The codex was remargined most probably at the time of binding. The folios 51-71 were added later. The colophon reads: tarîkh- $i$ nubum-i mâh-i Dhî al-Hijjah yawm al-abad sanab [...\{erased!\}] [bi-yad?] khâkbầy-i mubarrirân faqîr kabîr. W. Ivanow gave this manuscript to Dr. Casey A. Wood who estimated that it was originally written about 1487. This date is quoted in a note pasted on the verso of the last folio, written in Colombo, Ceylon, Dec., 10, 1926 and signed by Casey A. Wood.

\section{6 (A31) Figure 10}

A collection of eleven (out of the original thirty) parts (juz') of the Qur'an executed before 4 Ramadân 908/1503.

(1) ff.[37], $233 \times 164 / 167 \times 115 \mathrm{~mm} ., 7$ lines per page. Al-Juz' al-thânî (ch.2, v. 142-ch.2, v. 222). The present part is imperfect at the end and after f.23. Written on thick, non-European paper with laid lines only faintly visible. Fully vocalized Bihârî hand (without tarwîs). The codex opens with an illuminated circular shamsab and a doublepage frontispiece. The first two pages, the word Allâh, discs and florettes are executed in gold. The other illuminated elements include marginal medallions (nisf, thalâthat arbấ $\hat{a}^{\prime}$ ) and the letter 'ayn. The text is enclosed in blue and red rule-borders. It is provided with an interlinear Persian translation in red ink. No date.

(2) ff. [45]. Written by the same hand as above, this codex contains al-juz' al-khâmis (ch.4, v. 24-end of ch.4). It is provided with a waqf-note in Persian (ff. 45a-b) dated 4th of Ramadân 908/1503. The note gives the founder's name as Karam Allâh Nasr Allâh al-Mukhâtib, an official in charge of property (Mutasarrif-i Mamâlik-i Divân-i 'Alî) in the ministry of Shâh Bâbâr (thus), Mansûr al-Mulk ibn Mansûr al-Mulk and states that if there is anything missing from this $j u z$ ', it should be brought to the attention of Mas'ûd Nûr Sundûqî (i.e. the keeper of the sundîq, a box for housing copies of the Qur'an) of the fort (qal'ab) R.t(?).h.h.w.r, perhaps a corruption of Ranthambhor.

(3) ff. [33]. Executed by the same hand as the preceding parts, this is al-juz' al-thamin (ch.6, v. $111-$ ch. 7, v. 87). There is a lacuna after f. 26 


\section{A Collection of Qur'anic Codices}

and the folios 27-33 had been supplied in a different and later hand, without Persian interlinear translation.

(4) ff.[43]. This is al-juz' al-'âshir (ch.8, v.41-ch.9, v.93) of the same copy of the Qur'an. The folios 20-25 are badly mutilated. Appended to this part is the same waqf-note as above dated 4 Ramadân 908/1503.

(5) ff. [48]. Al-juz' al-khâmis 'ashar (ch.17, v. 1 -ch. 18 , v. 74). The folios $42-48$ were supplied later and have not Persian interlinear translation.

(6) ff. [38]. Al-Juz' al-sâdis 'ashar (ch.18, v.75-ch.20). Provided with the same waqfnote as above.

(7) ff. [37]. Al-Juz' al-tâsi' 'ashar (ch.15, v. $21-$ ch. 27 , v. 59).

The folio $37 \mathrm{~b}$ carries the introductory portion of the same waqf-note as above.

(8) ff. [42]] Al-Juz' al-bâdî wa-al-'ishrùn (ch. 29, v. 45-ch.33, v.30). The folio 42 a contains the end portion of the waqf-note.

(9) ff. [40]. Al-Juz' al-râbi' wa-al-'ishrûn (ch.39, v.32-ch.41, v.46). There is a lacuna after f. 38. Appended to this $j u z^{\prime}$ is the same waqf-note, dated 4 Ramaḍan 908/1503.

(10) ff. [44]. Al-Juz' al-kbâmis wa-al-'ishrîn (ch. 41 , v. 47 -ch. 45). It contains the initial portion of the same waqf-note.

(II) ff. [34]. Various fragments such as a portion of al-juz' al-thâmin and al-juz' al-thâmin 'ashar. The last folio carries the same waqfnote as above, dated 4 Ramadân 908/1503.

17 (A32)

ff. [7], $220 \times 155 / 180 \times 105 \mathrm{~mm}$., I I lines per page. A portion of the Qur'an containing Sûrat al-Mulk (67), Sûrat al-Dabr (76) and Sûrat al-Mursalât (77). Written on nonEuropean laid paper with thickish laid lines. Fully vocalized Naskh (with occasional but unsystematic use of tarwis), Muhaqqaq and golden Tawqî̀ scripts. The Muhaqqaq is used in the initial, median and final lines of the page and the Tawqî̀ for headings. The fragment begins with a badly damaged circular medallion and a double-page illumination and has the text divided into panels. The surabheadings, discs, rosettes are executed in gold and blue. The folios have been remargined. On the verso of the last folio there is a waqfnote written in the same hand as in no. 16 and dated Ramadân 908/1503.

18 (A33) Two parts (juz') of the Qur'an.

(1) ff. $[37], 230 \times 155 / 193 \times 107 \mathrm{~mm} ., 9$ lines per page. Juz' 22 (ch.33, v. 31-ch.36, v. 21). Written on non-European paper having thick and fairly regular laid lines. Fully vocalized Bihârî hand, with occasional left-sloping tarwîs. The sûrab-headings, recitation marks and rule-borders are in red ink. The verses are divided by means of a yellow circle with one red dot inside and four dots on the circumference. Note on the verso of folio 37. No date (early 10/16th century).

(2) ff. $[35], 210 \times 150 / 170 \times 108 \mathrm{~mm} ., 7$ and 9 lines per page. Juz' 23 (ch.36, v. $22-$ ch. 39, v. 31). Executed by the same hand as above (1). No date. 


\section{Notes}

I am greatly indebted to Dr. Eric Ormsby, Director of McGill University Libraries, for reading the final draft of this article and making valuable suggestions.

1. Adam Gacek, "Arabic calligraphy and the 'Herbal' of al-Ghâfiqî, a survey of Arabic manuscripts at McGill University," Fontanus 2 (1989), 37-53; idem, "Early Qur'anic fragments," Fontanus 3 (1990), 45-64.

2. See e.g. Solange Ory, "Un nouveau type de mushaf; inventaire des Corans en rouleaux de provenance damascaine conservés à Istanbul," Revue des études islamiques 33 (1965), 87-49.

3. Nabia Abbott, "Arabic paleography," Ars Islamica 8 (1941), 67; A.F.L. Beeston et al. Arabic literature to the end of the Umayyad period (Cambridge; Cambridge University Press, 1983), 22-23, 527, 528.

4. This is e.g. the case of the codex of Khâlid ibn Ma'dân (d. 103/721-2), see 'Abd Allâh ibn Abî Dâ'ûd al-Sijistânî, Kitâb al-masâbif (Beirut: Dâr al-Kutub al-'Ilmîyah, 1985), 150.

5. 'Alî ibn Ismâ‘îl ibn Sîdah, Kitâb al-mukbassas (Cairo, 1318-20 A.H.), v.4, pt.13, 8.

6. I'timâd Yûsuf al-Qusayrî, Fann tajlîd l-kitâb 'inda al-Muslimîn (Baghdad: al-Mu'assasah al-'Âmmah lil-Âthâr wa-alTurâth, 1979), 12.

7. Adam Gacek, "The ancient sijill of Uayrawan," MELA Notes 46 (1989), 26, 29, m. 11.

8. Jalâl al-Dîn al-Suyûtî, al-Itqân fî̀ 'ulû̀m d-Qur'ân (Osnabrück, 1980), 2:869-870.

9. See Bakr ibn Ibrâhîm al-Ishbîlî (d.628 or 629/1231 or 1232), "Kitâb al-taysîr fî sinâ'at d-tasfir," Revista del Instituto de Estudios islamicos en Madrid 7-8 (1959-60), 25. The use -n a string or a leather thong of this kind can dso be seen on outer, usually envelope-shaped ases used for extra protection of the bound codex.

10. Jeremiah P. Losty, The art of the book in ladia (London: British Library, 1982), 38-40.
11. See e.g. Adam Gacek, Arabic manuscripts in the libraries of McGill University, union catalogue (Montreal: McGill University Libraries, 1991), nos. 3/2, 13, 131, 140/1, 151, 225.

12. "Khatt," Encyclopaedia of Islam, new ed., (4), 1127; F. Déroche, Catalogue des manuscrits arabes, les manuscrits du Coran (Paris: Bibliothèque Nationale, 1985), 13, 140; D. James, Islamic calligraphy, sacred and secular writings (Geneva: Musée d'art et d'histoire, 1988), 166. 